\title{
Effects of Food Industry Wastewater Treatment Sludge on Corn Plant Development and Soil Properties
}

\author{
Mustafa Bıyıklı, Saliha Dorak ${ }^{1}$ Barış Bülent Aşık ${ }^{2 *}$ \\ ${ }^{1}$ Bursa Uludag University Graduate School of Natural and Applied Science, Bursa, Turkey \\ ${ }^{2}$ Bursa Uludag University Faculty of Agriculture, Department of Soil Science and Plant Nutrition, Bursa, Turkey
}

Received: 26 August 2019

Accepted: 8 October 2019

\begin{abstract}
In this study, agricultural usage of food industry wastewater treatment plant sludge was researched. Within the scope of our work the study was carried out in field conditions. Before sowing the maize, increasing levels of sludge (0-30-60 and 90 ton ha $\left.{ }^{-1}\right)$ were mixed with the soil. Three times plants were sampled during that period of development and crop harvest. Changes in soil properties caused by sludge application before planting and after harvest and the effect on corn plant growth and mineral content were determined.

According to the analysis results, the zinc contents of sludge used in this study were identified in terms of the value exceeding the limit specified in the regulations. Increasing amounts of sludge applied to soil increased the plant nutrient content, with positive effects on plant growth. Sludge reduced the $\mathrm{pH}$ and increased the $\mathrm{EC}$ of the soil before planting and after harvest. Together with the application of sludge, mainly to organic matter content, total $\mathrm{N}, \mathrm{NH}_{4}-\mathrm{N}, \mathrm{NO}_{3}-\mathrm{N}$ and available $\mathrm{P}, \mathrm{K}$ some microelement (Zn) and heavy metal content of the soil increased.
\end{abstract}

Keywords: sludge, lime stabilization, agricultural use, soil properties, plant

\section{Introduction}

Preservation of the natural environment is increasingly important nowadays. This is possible if the waste causing environmental pollution is disposed of in an environmentally friendly manner. Wastewater sludge is called solid, semi-solid or liquid residues, resulting from the physical, chemical and biological processes of domestic and industrial wastewater

*e-mail: bbasik@uludag.edu.tr
[1]. Land application of wastewater sludge is an economically attractive waste management strategy, largely promoted by scientists. Furthermore, it has been a socially accepted practice for decades in many parts of the World [2-4].

The land application of wastewater sludge in developed countries is highly controlled in order to prevent risks to public health and the environment. Sewage sludge must be treated and 'stabilized' to reduce odor, pathogen content and vector attraction, and is usually also mechanically dewatered or airdried to reduce bulk, to generate a product acceptable for beneficial use [5]. Sludge treatment may be through 
either one or a combination of the following generic methods:

(1) Biological processes (anaerobic or aerobic digestion, composting)

(2) Chemical processes (lime treatment).

(3) Physical processes (pasteurization, thermal hydrolysis, thermal drying, air or solar drying).

The US and EU has established federal requirements for the safe treatment, beneficial use, and disposal of biosolids. For wastewater sludge that is to be beneficially used, lime stabilization is one of the technologies identified to meet the requirements addressing pathogens.

Incremental sludge from industrial activities, especially without any stabilization, can contain highto-heavy metals and pathogens, bacteria and protozoans that were both harmful to human health and harmful to the odor [6]. For this reason some stabilization methods were applied to wastewater treatment sludges. Stabilization has as its main objectives: the reduction of fermentability, of odor emissions (through chemical and thermal treatment), and of bacteria and suspended solids (through biological process, aerobic or anaerobic). In chemical stabilization the inhibition of the biological reactions is performed by the increase of the $\mathrm{pH}$ of the wastewater sludge, up to values of around 12 . The stabilization treatment with lime is carried out by mixing the sludge with lime and water, resulting in the formation of an alkaline environment. At the end of the process, $\mathrm{pH}$ values above 10 are achieved for a certain period $[7,8]$. High $\mathrm{pH}$ brings an unfavorable environment for microorganisms. As a result, the sludge does not decompose, the smell disappears and health problems do not come to an end. The reuse of limestabilized sludge is not limited to use on farmland. These sludges have also been used as a soil substitute for landfill cover, for example. Exceptional quality sludges can also be sold to the public for use as commercial fertilizer or soil conditioner. The agricultural utilization of sludge has been considered as an environmentally acceptable management strategy [9]. SS contains high levels of organic matter ( $20 \%$ and more) and essential plant nutrients that can help/enhance crop production [10-13]

Food-based treatment sludge, which is an industrial waste used by human beings, is thought not to have negative features. It also thought that it may be used in agriculture from the view of plant nutrient elements and organic matter [14]. However, the determination of the characteristics of these wastes before their application to the soil will be more beneficial in terms of agricultural use and environmental impact [15]. Otherwise, it was very difficult to remove the negative effects of wastes containing harmful factors for soil ecosystem and plant growth [16]. In this study we tried to determine the possibility of being used in agriculture by taking into account some agricultural characteristics of limeapplied treatment sludge.

\section{Experimental}

\section{Establishment and Execution}

The lime-stabilized sludge (LTS) used in the research was taken from Natura Food Industry Inc. Lime treatment is one of the methods sanctioned in the regulations. To meet vector attraction reduction requirements using lime, the $\mathrm{pH}$ must be raised to 12 or higher for 2 hours and subsequently maintained above $\mathrm{pH} 11,5$ for another 22 hours without further alkali addition.

The factorial experiment was arranged in a completely randomized block design with three replications per treatment. The plot size was $3 \mathrm{x}$ $10=30 \mathrm{~m}^{2}$. In the experimental treatment, the sludge was applied to the soil at 0 (control), 30 (dose 1), 60 (dose 2) and 90 (dose 3) tonnes ha ${ }^{-1}$ according to them based on dry matter and mixed with the soil.

The soil used in the experiment had a clay loam texture and the $\mathrm{pH}$ indicated that the soil was slightly alkaline, which is common for soils in Turkey. The soil had low organic matter and salt contents. The soil had adequate levels of $\mathrm{N}, \mathrm{P}, \mathrm{K}, \mathrm{Fe}, \mathrm{Mn}$, and $\mathrm{Zn}$, and a low $\mathrm{Cu}$ content. The limed sludge was applied to the soil and mixed before sowing. At the end of the one-month incubation period, a silage corn variety was cultivated. Within the scope of the experiment, phenological observations were made in the field, and plant leaf samples were taken in 3 sampling periods (V3: three leaf collars, R1: silking and R5: dent-nearly all kernels are denting) and then harvested. The analysis made on plant and grain samples are given below. In order to determine the effect of applied sludge on soil properties, after sludge application pre-plant and postharvest samples from $0-30 \mathrm{~cm}$ depth were duly taken from all the plots for chemical analysis.

\section{Limed-Stabilized Sludge, Soil and Plant Analysis}

The wastewater sludge sample and soil were analyzed for basic physicochemical properties using standard procedures and results are presented in Table 1. A portion of the sample to be used in the analysis of the treatment sludge used in the trial was sieved from $2 \mathrm{~mm}$ after drying at $65^{\circ} \mathrm{C}$. In the case of limed treatment sludge, reaction $(\mathrm{pH})$, electrical conductivity (EC) [17, 18], and sludge organic matter content was determined by ashing at $550^{\circ} \mathrm{C}$ [19]. Total $\mathrm{N}$ according to Kjeldahl method; ammonia $\left(\mathrm{NH}_{4}-\mathrm{N}\right)$ [19]; nitrate $\left(\mathrm{NO}_{3}-\mathrm{N}\right)$ [20]; total $\mathrm{P}, \mathrm{K}, \mathrm{Na}, \mathrm{Mg}$ and $\mathrm{Ca}$; and heavy metals $(\mathrm{Pb}, \mathrm{Cd}$, $\mathrm{Cr}, \mathrm{Ni}, \mathrm{Cu}, \mathrm{Zn}, \mathrm{Fe}$, and $\mathrm{Mn}$ ) in the solution obtained by wet digestion with $\mathrm{HNO}_{3}$ in a microwave oven were determined by Perkin Elmer Optima 2100 DV ICP [21]. According to Table 1, the concentrations of heavy metals in this particular sludge are below the limits imposed by the European and National guidelines for the agricultural utilization of sludge (except for $\mathrm{Zn}$ ). 
Table 1. Some analytical values of experimental soil and limestabilized sludge (LTS).

\begin{tabular}{|c|c|c|c|}
\hline Properties & Soil & LTS & Anonim 2010 \\
\hline$\%$ clay & 43,1 & & \\
\hline$\%$ loam & 27,4 & & \\
\hline$\%$ sand & 29,7 & & \\
\hline $\mathrm{pH}$ & 7,73 & 12,4 & \\
\hline $\mathrm{EC}, \mu \mathrm{S} \mathrm{cm}^{-1}$ & 161,8 & 3,50 & \\
\hline OM, \% & 1,37 & 48,8 & \\
\hline $\mathrm{N}, \%$ & 0,12 & 3,86 & \\
\hline $\mathrm{NH}_{4}-\mathrm{N}, \mathrm{mg} \mathrm{kg}^{-1}$ & 59,37 & trace & \\
\hline $\mathrm{NO}_{3}-\mathrm{N}, \mathrm{mg} \mathrm{kg}^{-1}$ & 2,69 & trace & \\
\hline $\mathrm{P}, \%$ & $55,93 *$ & $1,63^{* *}$ & \\
\hline $\mathrm{K}, \%$ & $140,14^{*}$ & $0,48^{* *}$ & \\
\hline $\mathrm{Ca}, \%$ & $301,21^{*}$ & $30,6^{* *}$ & \\
\hline $\mathrm{Mg}, \%$ & $252,05^{*}$ & $0,69 * *$ & \\
\hline $\mathrm{Na}, \%$ & $76,23 *$ & $0,17 * *$ & \\
\hline $\mathrm{Pb}, \mathrm{mg} \mathrm{kg}^{-1}$ & trace & $12,1^{* *}$ & 750 \\
\hline $\mathrm{Cd}, \mathrm{mg} \mathrm{kg}^{-1}$ & $1,877^{*}$ & $1,36^{* *}$ & 10 \\
\hline $\mathrm{Cr}, \mathrm{mg} \mathrm{kg}^{-1}$ & $0,071 *$ & $110,3^{* *}$ & 1000 \\
\hline $\mathrm{Ni}, \mathrm{mg} \mathrm{kg}^{-1}$ & $1,199 *$ & $16,24 * *$ & 300 \\
\hline $\mathrm{Cu}, \mathrm{mg} \mathrm{kg}^{-1}$ & $0,032 *$ & $42,03 * *$ & 1000 \\
\hline $\mathrm{Zn}, \mathrm{mg} \mathrm{kg}^{-1}$ & $3,871 *$ & $12420 * *$ & 2500 \\
\hline $\mathrm{Fe}, \%$ & $43,95^{*}$ & $5,142 * *$ & \\
\hline $\mathrm{Mn}, \mathrm{mg} \mathrm{kg}^{-1}$ & $2,072 *$ & $145,6^{* *}$ & \\
\hline
\end{tabular}

*. Available (DTPA and $\left.\mathrm{NH}_{4} \mathrm{OAc}, \mathrm{mg} \mathrm{kg}^{-1}\right)$, **. Total $\left(\mathrm{HNO}_{3}\right)$

In the study, soil samples were taken pre-planting and post-harvest at 0-30 $\mathrm{cm}$ depth, soils were dried in air conditions and sieved from $2 \mathrm{~mm}$. Soil $\mathrm{pH}$ and EC were measured with a $\mathrm{pH}$ meter and conductivity meter using a water ratio of 1:2.5 w/v respectively. Soil texture was determined using the hydrometer method, lime was determined using the calsimetric method, organic matter content was analyzed according to the modified Walkley-Black method, total $\mathrm{N}$ was determined using a Buchi K-437/K-350 digestion/distillation unit according to the Kjeldahl method, and ammonium-N and nitrate- $\mathrm{N}$ concentrations were determined with $2 \mathrm{M} \mathrm{KCl}$ extracts using the indophenol blue method and the salicylic acid method. Available P was determined using a PG Instruments T60 Split Beam UV/VIS model spectrophotometer according to the molybdenum blue method. Exchangeable cations $(\mathrm{Na}, \mathrm{K}, \mathrm{Ca}$ and $\mathrm{Mg}$ ) were extracted with ammonium acetate at $\mathrm{pH}$ 7,0 and measured using an Eppendorf Elex 6361 model Flame Photometer. Available $\mathrm{Fe}, \mathrm{Cu}, \mathrm{Zn}, \mathrm{Mn}, \mathrm{Cd}, \mathrm{Cr}, \mathrm{Ni}$ and $\mathrm{Pb}$ were extracted with diethylene triamine pentaacetic acid (DTPA) $(0.005$ M $\quad$ DTPA $+0.01 \quad \mathrm{M} \quad \mathrm{CaCl} 2+0.1$ $\mathrm{M}$ TEA $\mathrm{pH}$ 7.3) and measured with a Perkin Elmer 2100DV ICP OES [22].

Plant and grain samples taken during the growing season and dried at $65^{\circ} \mathrm{C}$ to constant weight in a pneumatic dryer and prepared for analysis by grinding in the plant grinding mill. Total nitrogen in plant samples was determined by the Kjeldahl method. Plant samples were digested with a mixture of nitric acidhydrogen peroxide $\left(\mathrm{HNO}_{3}+\mathrm{H}_{2} \mathrm{O}_{2}\right)$ in a Berghof MWS2 model microwave oven. With the obtained solution, phosphorus $(\mathrm{P})$, sodium $(\mathrm{Na})$, potassium $(\mathrm{K})$, calcium $(\mathrm{Ca})$, magnesium $(\mathrm{Mg})$, and heavy metals $(\mathrm{Pb}, \mathrm{Cd}, \mathrm{Cr}$, $\mathrm{Ni}, \mathrm{Cu}, \mathrm{Fe}, \mathrm{Mn}$ and $\mathrm{Zn}$ ) were determined by a Perkin Elmer Optima 2100 DV ICP OES [23].

The data obtained from the study were statistically evaluated with the JUMP package program, and the LSD test $(p<0,05 ; p<0,01)$ was used to compare the differences between the averages.

\section{Results and Discussion}

\section{Effect of Lime-Stabilized Sludge on Soil Properties}

In the study, soil samples were collected before planting and after harvesting from the plots applied to determine the effects of the lime-stabilized sludge (LTS) on the soil properties.

Effects of the limed treatment sludge applications before planting and after harvesting include soil properties such as $\mathrm{pH}, \mathrm{EC}$, organic matter, total nitrogen, ammonium and nitrate, available phosphorus and DTPA-extractable microelements (Fe, Cu, Zn ve $\mathrm{Mn})$ and heavy metal contents $(\mathrm{Cd}, \mathrm{Cr}, \mathrm{Ni}$ ve $\mathrm{Pb})$. Differences caused by applications were grouped by the LSD test and reported in the relevant tables.

Changes in soil $\mathrm{pH}, \mathrm{EC}$ and organic matter content caused by the increasing amount of lime sludge are shown in Table 1 and Fig. 1. The lowest $\mathrm{pH}$ value was determined as the average of the control $(\mathrm{pH}$ 7.27) and the highest $\mathrm{pH}$ value was $90 \mathrm{t} \mathrm{ha}^{-1}(\mathrm{pH} 7.85)$. The increase in $\mathrm{pH}$ is attributed to the high concentrations of $\mathrm{CaCO}_{3}$ in the lime-stabilized sludge. (Table 2). The low $\mathrm{pH}$ value of the post-harvest soil was related to mineralization and organic acids. The decrease in soil $\mathrm{pH}$ is due to organic acids produced during sludge decomposition. Another explanation is the reduction in soil $\mathrm{pH}$ probably due to nitrification of $\mathrm{NH}_{4}-\mathrm{N}$ from the sludge [24]. With regard to the change in the soil $\mathrm{pH}$ with the treatment sludge application, the sludge reduced the soil $\mathrm{pH}$ value of sludge applied to alkaline or neutral soils reported by researchers $[25,26]$.

Depending on the increasing application LTS levels, the average pre-planting and post-harvest EC value of the soil increased. The lowest EC value was determined as $221,5 \mu \mathrm{S} \mathrm{cm}^{-1}$ in control plots not applied to sludge, and the highest value was $645,4 \mu \mathrm{S} \mathrm{cm}^{-1}$ in the $90 \mathrm{t} \mathrm{ha}^{-1}$ 
Table 2. Effects of lime-stabilized sludge on $\mathrm{pH}$, EC and organic matter content.

\begin{tabular}{|c|c|c|c|c|c|c|c|c|c|c|}
\hline \multirow{2}{*}{\multicolumn{2}{|c|}{$\begin{array}{c}\text { Treatments ton } \\
\text { ha }^{-1}\end{array}$}} & \multicolumn{3}{|c|}{$\mathrm{pH}$} & \multicolumn{3}{|c|}{$\mathrm{EC} \mu \mathrm{S} \mathrm{cm}^{-1}$} & \multicolumn{3}{|c|}{ O.M. \% } \\
\hline & & BS & $\mathrm{AH}$ & Means & BS & $\mathrm{AH}$ & Means & BS & $\mathrm{AH}$ & Means \\
\hline \multicolumn{2}{|c|}{ Control } & 7,29 & 7,24 & $7,27 \mathrm{~B}^{*}$ & 219,8 & 223,1 & $221,5 \mathrm{C}^{* *}$ & 1,85 & 1,64 & $1,75 \mathrm{~B}^{*}$ \\
\hline \multicolumn{2}{|r|}{30} & 7,64 & 7,68 & $7,66 \mathrm{~A}^{*}$ & 371,3 & 340,0 & $355,7 \mathrm{BC}^{* *}$ & 2,03 & 2,14 & $2,09 \mathrm{~B}^{*}$ \\
\hline \multicolumn{2}{|r|}{60} & 7,76 & 7,60 & $7,68 A^{*}$ & 552,0 & 356,3 & $454,2 \mathrm{~B}^{* *}$ & 2,28 & 2,32 & $2,30 \mathrm{~B}^{*}$ \\
\hline \multicolumn{2}{|r|}{90} & 7,97 & 7,73 & $7,85 \mathrm{~A}^{*}$ & 656,7 & 634,0 & $645,4 \mathrm{~A}^{* *}$ & 2,96 & 2,90 & $2,93 \mathrm{~A}^{*}$ \\
\hline \multicolumn{2}{|c|}{ Means } & 7,67 & 7,56 & & 449,95 & 388,35 & & 2,28 & 2,25 & \\
\hline \multicolumn{11}{|c|}{ BS: before sowing, AH: After harvest } \\
\hline LSD & Dose & \multicolumn{2}{|c|}{0,234} & & \multicolumn{2}{|c|}{134,5} & & \multicolumn{2}{|c|}{0,559} & \\
\hline \multicolumn{2}{|c|}{ Period } & \multicolumn{2}{|c|}{ nd } & & \multicolumn{2}{|c|}{ nd } & & \multicolumn{2}{|c|}{ nd } & \\
\hline \multicolumn{2}{|c|}{$\mathrm{D} * \mathrm{P}$} & \multicolumn{2}{|c|}{ nd } & & \multicolumn{2}{|c|}{ nd } & & \multicolumn{2}{|c|}{ nd } & \\
\hline
\end{tabular}

application. The increase in EC value due to increasing levels is due to the chemical properties of the sludge and the mineralization due to time. The increase in salinity is one of the most important factors to be considered in agricultural applications [27, 28]. Excessive application of soil may lead to the EC limit of salinity. According to the pre-sowing of the soil
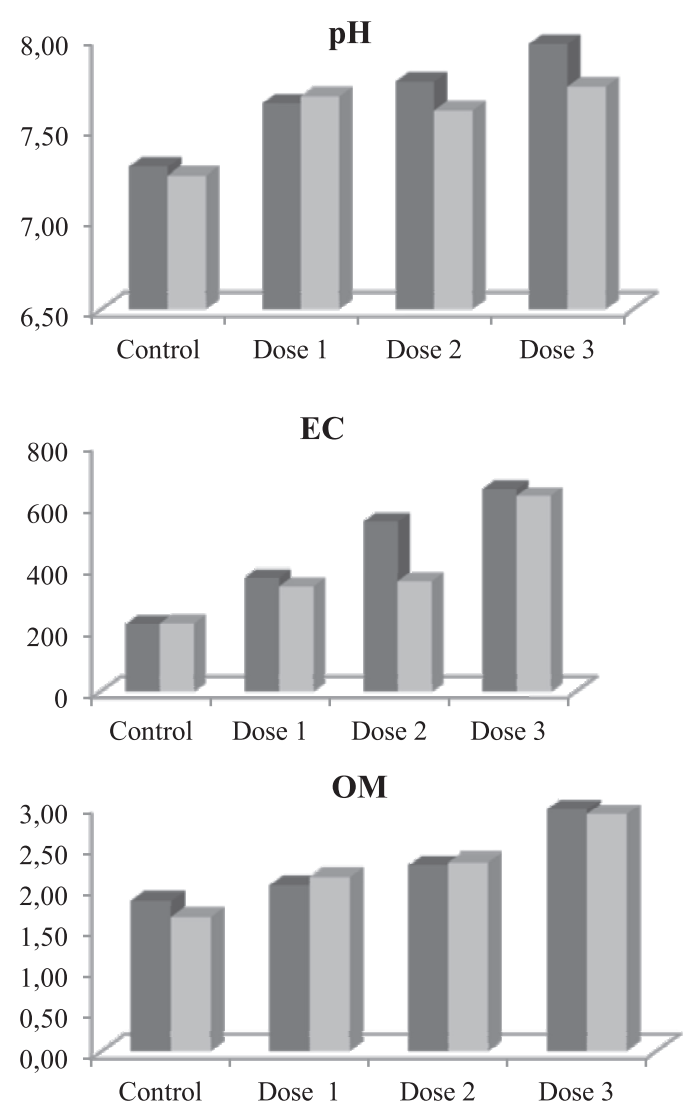

Fig. 1. Effects of lime-stabilized sludge on $\mathrm{pH}, \mathrm{EC}$ and organic matter content under increasing levels of pre-planting and postharvest soil. samples taken after harvest, EC value decreased. This may be related to plant intake.

The soil organic matter value increased as averages before planting and after harvest, depending on the increasing application levels. The lowest organic matter value was $1,75 \%$ for the untreated control plot and the highest value was $2,93 \%$ for the $90 \mathrm{t} \mathrm{ha}^{-1}$ application. Increasing levels of sewage sludge have been identified in many studies that increase soil organic matter content. Wastewater treatment sludge can be used to solve organic matter deficiencies, especially due to the high organic matter content [29]. In addition, the mineralization of the more easily degradable forms of sludge organic matter by soil microorganism is rapid, depending upon soil conditions [30].

The changes that the LTS brings to the soil $\mathrm{N}(\%)$, $\mathrm{NH}_{4}-\mathrm{N}\left(\mathrm{mg} \mathrm{kg}^{-1}\right)$ and $\mathrm{NO}_{3}-\mathrm{N}\left(\mathrm{mg} \mathrm{kg}^{-1}\right)$ and the available $\mathrm{P}\left(\mathrm{mg} \mathrm{kg}^{-1}\right)$ value are given in Table 3 and Fig. 2 .

The soil $\mathrm{N} \%$ values increased before and after harvest depending on the increased application levels. The lowest $\mathrm{N}$ value was determined in the control plot, and the highest value was found to be $0,17 \%$ and $0,28 \%$ at $90 \mathrm{t} \mathrm{ha}^{-1}$ application. The sludge doses and the application of fertilizer to the total $\mathrm{N}$ content of soils were statistically significant in that the sludge was applied at increasing rates, increasing the total nitrogen content as well as that the soil was in the organic matter content. Numerous studies have been carried out to investigate the effects of sludge applications on plant nutrients in the soil [31-33].

The average values of the $\mathrm{NH}_{4}-\mathrm{N}$ and $\mathrm{NO}_{3}-\mathrm{N}$ (mg kg-1) increased before sowing and after harvest depending on the increasing application levels. The highest values were determined at $90 \mathrm{t} \mathrm{ha}^{-1}$ application. This increase was related to the chemical properties of the sludge. The increase in the amount of $\mathrm{NO}_{3}-\mathrm{N}\left(\mathrm{mg} \mathrm{kg}^{-1}\right)$ in the soil due to the time of incubation was related to nitrification [23]. Soil type, sludge properties and soil $\mathrm{pH}$, temperature, aeration 
Table 3. Effects of lime-stabilized sludge on soil $\mathrm{N} \%, \mathrm{NH}_{4}, \mathrm{NO}_{3}$, available $\mathrm{P}$ content.

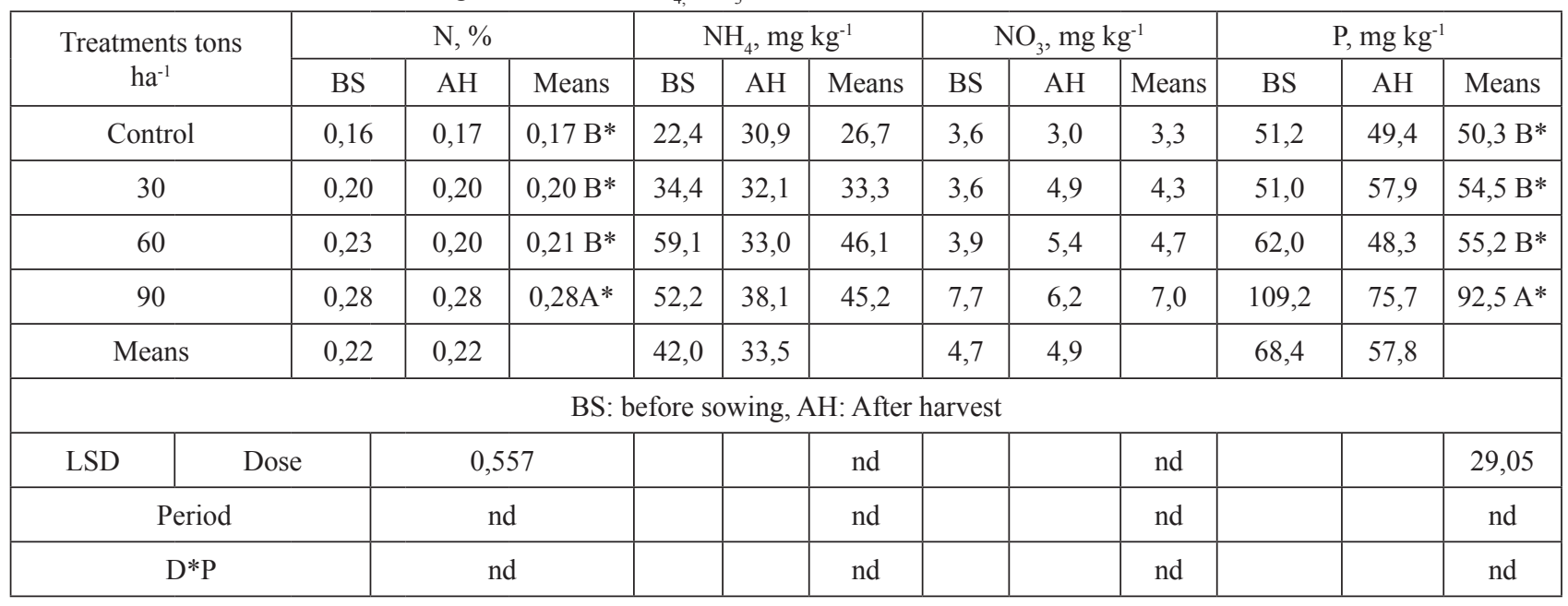

*. $\mathrm{p}<0,05, * * . \mathrm{p}<0,01$
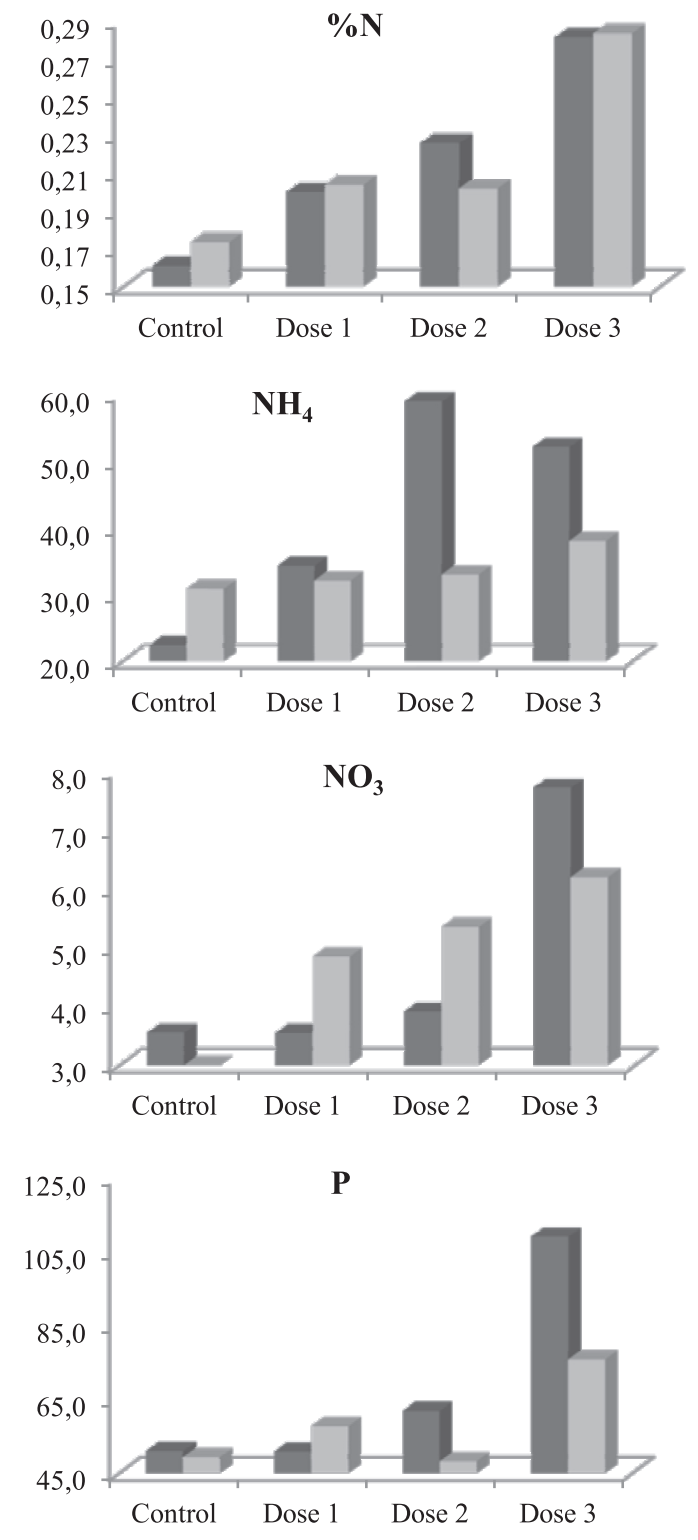

Fig. 2. Effects of lime-stabilized sludge on soil $\mathrm{N}, \mathrm{NH}_{4}, \mathrm{NO}_{3}$ and available $\mathrm{P}$ content under increasing levels. and humidity conditions were especially influential on the final organic nitrogen mineralization of sludge applications. Therefore, it was important to know the organic and inorganic forms of nitrogen in order to determine the nitrogen fertilizer value of the treatment sludge, which was considered to be applied to the soil and to predict how the organic nitrogen will be mineralized during the plant production period [34]. For example, about the subject the rate of agricultural application of biosolids is determined by the nitrogen limited biosolids application rate, where the amount of PAN (plant-available N) applied in biosolids (calculated according to Eq. (PAN $\mathrm{Plant}_{\text {available } \mathrm{N}}=\mathrm{NH}_{4}-\mathrm{N}+\left[\mathrm{NO}_{3}\right.$ $\left.\mathrm{N}+\mathrm{NO}_{2}-\mathrm{N}\right]+$ mineralizable $\mathrm{N}$ ) must not exceed the crop $\mathrm{N}$ requirement in the year of application. It is important to consider the above formula [35, 36].

Depending on the increased application levels, before planting and after harvest soil was determined at the lowest available $\mathrm{P}$ values of $50,3 \mathrm{mg} \mathrm{kg}^{-1}$ and the highest $\mathrm{P}$ value of $92,5 \mathrm{mg} \mathrm{kg}^{-1}$ at $90 \mathrm{t} \mathrm{ha}^{-1}$ application. Phosphorus availability in sludge is strongly influenced by the wastewater treatment (WWT) processes [37]. The addition of some type of liming agent to stabilize sludge may result in lower total $\mathrm{P}$. The addition of lime was reported to increase sludge $\mathrm{pH}$ and decrease the solubility of $\mathrm{P}$ by the formation of recalcitrant caphosphate minerals [38]. Since more stringent $N$ and $\mathrm{P}$ discharge limits have been implemented in wastewater treatment plants (WWTP) in environmentally sensitive areas, total $\mathrm{P}$ in sludge is expected to increase from current values [39]. Heavy applications of wastewater sludge in order to supply sufficient inorganic $\mathrm{N}$ and meet crop $\mathrm{N}$ demands will most probably oversupply $\mathrm{P}$ [40].

The changes that the lime-stabilized sludge caused to the soil-exchangeable $\mathrm{Na}, \mathrm{K}, \mathrm{Ca}$ and $\mathrm{Mg}$ values are given in Table 4 and Fig. 3 The $\mathrm{Na}, \mathrm{K}, \mathrm{Ca}$ and $\mathrm{Mg}$ values increased as the before sowing and after harvest averages, depending on the increased application 
Table 4. Effect of increasing amounts of LTS on the exchangeable $\mathrm{Na}, \mathrm{K}, \mathrm{Ca}$ and $\mathrm{Mg}$ contents.

\begin{tabular}{|c|c|c|c|c|c|c|c|c|c|c|c|c|c|}
\hline \multirow{2}{*}{\multicolumn{2}{|c|}{$\begin{array}{l}\text { Treatments } \\
\text { tons } \mathrm{ha}^{-1}\end{array}$}} & \multicolumn{3}{|c|}{$\mathrm{Na}, \mathrm{mg} \mathrm{kg}^{-1}$} & \multicolumn{3}{|c|}{$\mathrm{K}, \mathrm{mg} \mathrm{kg}^{-1}$} & \multicolumn{3}{|c|}{$\mathrm{Ca}, \mathrm{mg} \mathrm{kg}^{-1}$} & \multicolumn{3}{|c|}{$\mathrm{Mg}, \mathrm{mg} \mathrm{kg}^{-1}$} \\
\hline & & BS & $\mathrm{AH}$ & Means & BS & $\mathrm{AH}$ & Means & BS & $\mathrm{AH}$ & Means & $\mathrm{BS}$ & $\mathrm{AH}$ & Means \\
\hline \multicolumn{2}{|c|}{ Control } & $75 c^{*}$ & $63 \mathrm{c}^{*}$ & $691 C *$ & 139 & 203 & 171B* & $287 \mathrm{~d}^{*}$ & $237 e^{*}$ & $262 \mathrm{C} * *$ & 264 & 272 & $268 B^{*}$ \\
\hline \multicolumn{2}{|c|}{30} & $152 b^{*}$ & $84 c^{*}$ & $118 \mathrm{~B}^{*}$ & 143 & 336 & $240 B *$ & $354 \mathrm{bc}^{*}$ & $318 \mathrm{~cd}^{*}$ & $336 \mathrm{~B} * *$ & 260 & 276 & $268 \mathrm{~B} *$ \\
\hline \multicolumn{2}{|c|}{$60^{1}$} & $248 a^{*}$ & $93 \mathrm{bc} *$ & $170 A^{*}$ & 201 & 276 & $238 B *$ & $461 a^{*}$ & 338 bc* & $399 \mathrm{~A} * *$ & 303 & 316 & $309 A^{*}$ \\
\hline \multicolumn{2}{|c|}{90} & $277 a^{*}$ & $97 b c^{*}$ & $187 A^{*}$ & 308 & 483 & $395 A^{*}$ & $471 \mathrm{a}^{*}$ & $369 b^{*}$ & $420 A^{* *}$ & 329 & 346 & $338 A^{*}$ \\
\hline \multicolumn{2}{|c|}{ Means } & $188 \mathrm{~A}^{* *}$ & $84,2 \mathrm{~B} * *$ & & 198 B* & $324 A^{*}$ & & $393 \mathrm{~A}^{* *}$ & $315 \mathrm{~B} * *$ & & 289 & 303 & \\
\hline \multicolumn{14}{|c|}{ BS: before sowing, AH: After harvest } \\
\hline LSD & Dose & & & 46,59 & & & 86,55 & & & 33,75 & & & 37,86 \\
\hline \multicolumn{2}{|c|}{ Period } & & & 32,95 & & & 61,20 & & & 23,86 & & & nd \\
\hline \multicolumn{2}{|c|}{$\mathrm{D} * \mathrm{P}$} & & & 65,89 & & & nd & & & 47,73 & & & nd \\
\hline
\end{tabular}

*. $\mathrm{p}<0,05, * * . \mathrm{p}<0,01$
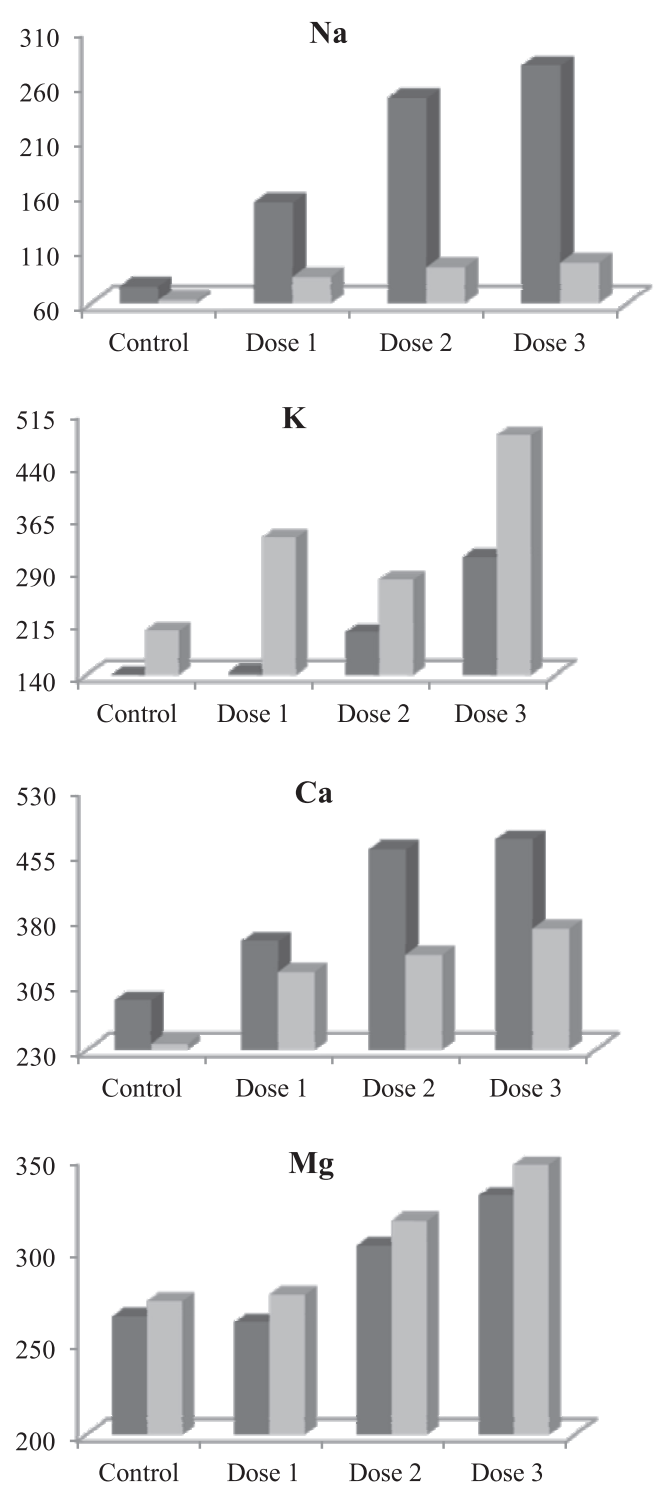

Fig. 3. Effect of increasing amounts of limed sludge on the exchangeable $\mathrm{Na}, \mathrm{K}, \mathrm{Ca}$ and $\mathrm{Mg}$ contents of pre-planting and post-harvest soil. levels. The lowest values were 69.1, 171.8, 262.0 and $268.5 \mathrm{mg} \mathrm{kg}^{-1}$, respectively, and the highest values were 187.0, 395.9, 420.4 and $338.4 \mathrm{mg} \mathrm{kg}^{-1}$ as determined at $90 \mathrm{t} \mathrm{ha}^{-1}$ application.

Sludges contain $\mathrm{N}$ and $\mathrm{P}$ as well as more or less $\mathrm{K}$, $\mathrm{Ca}, \mathrm{Mg}$ and $\mathrm{Na}$ plant nutrients [41, 42]. It should be noted that in the course of application to the soil, the amount of these elements, together with the application, was given to the soil and does not disturb the nutrient balance in the soil. In the studies carried out, the low correlation between the amounts of $\mathrm{Ca}, \mathrm{Mg}, \mathrm{Na}$ and $\mathrm{K}$ of the soil and the plant was obtained due to the treatment sludge applications [24].

The changes caused by lime-stabilized sludge in soil DTPA-extractable $\mathrm{Fe}, \mathrm{Zn}, \mathrm{Mn}$ and $\mathrm{Cu}$ values are shown in Table 5 and Fig. 4. Depending on the increasing application levels, the average content of $\mathrm{Fe}, \mathrm{Zn}, \mathrm{Mn}$, and $\mathrm{Cu}$ can be increased before sowing and after harvesting. The lowest values were determined as 24,8 , 5,2, 24,9 and 3,3 $\mathrm{mg} \mathrm{kg}^{-1}$ in control, while the highest values were $28,7,119,9,29,2$ and 4,1 in 90 tonnes $^{-1}$ respectively. When the changes in the microelement content of the soil before sowing and after harvesting are examined, it is seen that the most significant change is in $\mathrm{Zn}$. The reason for this change is due to the high $\mathrm{Zn}$ content of the calcareous sludge used (Table 1). Zn content of this food industry treatment sludge is very high [41, 42].

Fig. 5 shows the changes in the amount of DTPAextractable heavy metals $(\mathrm{Ni}, \mathrm{Cr}, \mathrm{Pb}, \mathrm{Cd})$ in the preplanting and post-harvest soil. The change was not statistically significant. This situation was caused by the increase in the organic matter content of the soils depending on the application levels and the formation of complex compounds due to mineralization and the change of the chemical properties of the treated sludge by the lime application. This possibly indicates that the decomposition of organic matter in the soil did not control the availability of DTPA extractable metals, 
Table 5. Effect of increasing amounts of limed sludge on $\mathrm{Fe}, \mathrm{Zn}, \mathrm{Mn}$, and $\mathrm{Cu}$ contents of the soil.

\begin{tabular}{|c|c|c|c|c|c|c|c|c|c|c|c|c|c|}
\hline \multirow{2}{*}{\multicolumn{2}{|c|}{$\begin{array}{l}\text { Treatments } \\
\text { tons } \mathrm{ha}^{-1}\end{array}$}} & \multicolumn{3}{|c|}{$\mathrm{Fe}, \mathrm{mg} \mathrm{kg}^{-1}$} & \multicolumn{3}{|c|}{$\mathrm{Zn}, \mathrm{mg} \mathrm{kg}^{-1}$} & \multicolumn{3}{|c|}{$\mathrm{Mn}, \mathrm{mg} \mathrm{kg}^{-1}$} & \multicolumn{3}{|c|}{$\mathrm{Cu}, \mathrm{mg} \mathrm{kg}^{-1}$} \\
\hline & & BS & $\mathrm{AH}$ & Means & BS & $\mathrm{AH}$ & Means & BS & $\mathrm{AH}$ & Means & BS & $\mathrm{AH}$ & Means \\
\hline \multicolumn{2}{|c|}{ Control } & 23,4 & 26,3 & 24,8 & $4,7 \mathrm{c}^{* *}$ & $5,7 \mathrm{c} * *$ & $5,2 \mathrm{C}^{* *}$ & 25,0 & 24,9 & 24,9 & 3,35 & 3,25 & $3,3 \mathrm{~B}^{*}$ \\
\hline \multicolumn{2}{|c|}{30} & 24,0 & 25,4 & 24,7 & $15,3 \mathrm{c}^{* *}$ & $48,7 \mathrm{bc}^{* *}$ & $32,0 \mathrm{BC} * *$ & 24,9 & 25,6 & 25,2 & 3,68 & 3,86 & $3,8 \mathrm{AB}^{*}$ \\
\hline \multicolumn{2}{|c|}{60} & 28,0 & 26,3 & 27,2 & $43,2 \mathrm{bc}^{* *}$ & $87,8 b^{* *}$ & $65,5 \mathrm{~B} * *$ & 27,4 & 26,8 & 27,1 & 3,72 & 4,10 & $3,9 \mathrm{~A}^{*}$ \\
\hline \multicolumn{2}{|c|}{90} & 31,2 & 26,3 & 28,7 & $52,6 \mathrm{bc}^{* *}$ & $187,1 \mathrm{a}^{* *}$ & $119,9 \mathrm{~A}^{* *}$ & 32,2 & 26,2 & 29,2 & 4,03 & 4,16 & $4,1 \mathrm{~A}^{*}$ \\
\hline \multicolumn{2}{|c|}{ Means } & 26,7 & 26,1 & & $28,9 \mathrm{~B} * *$ & $82,3 \mathrm{~A}^{* *}$ & & 27,4 & 25,9 & & 3,70 & 3,84 & \\
\hline \multicolumn{14}{|c|}{ BS: before sowing, AH: After harvest } \\
\hline LSD & Dose & & & nd & & 32,39 & & & & nd & & & nd \\
\hline \multicolumn{2}{|c|}{ Period } & & & nd & & 45,81 & & & & nd & & & nd \\
\hline \multicolumn{2}{|c|}{$\mathrm{D}^{*} \mathrm{P}$} & & & nd & & 64,78 & & & & nd & & & nd \\
\hline
\end{tabular}

*. $\mathrm{p}<0,05, * * . \mathrm{p}<0,01$
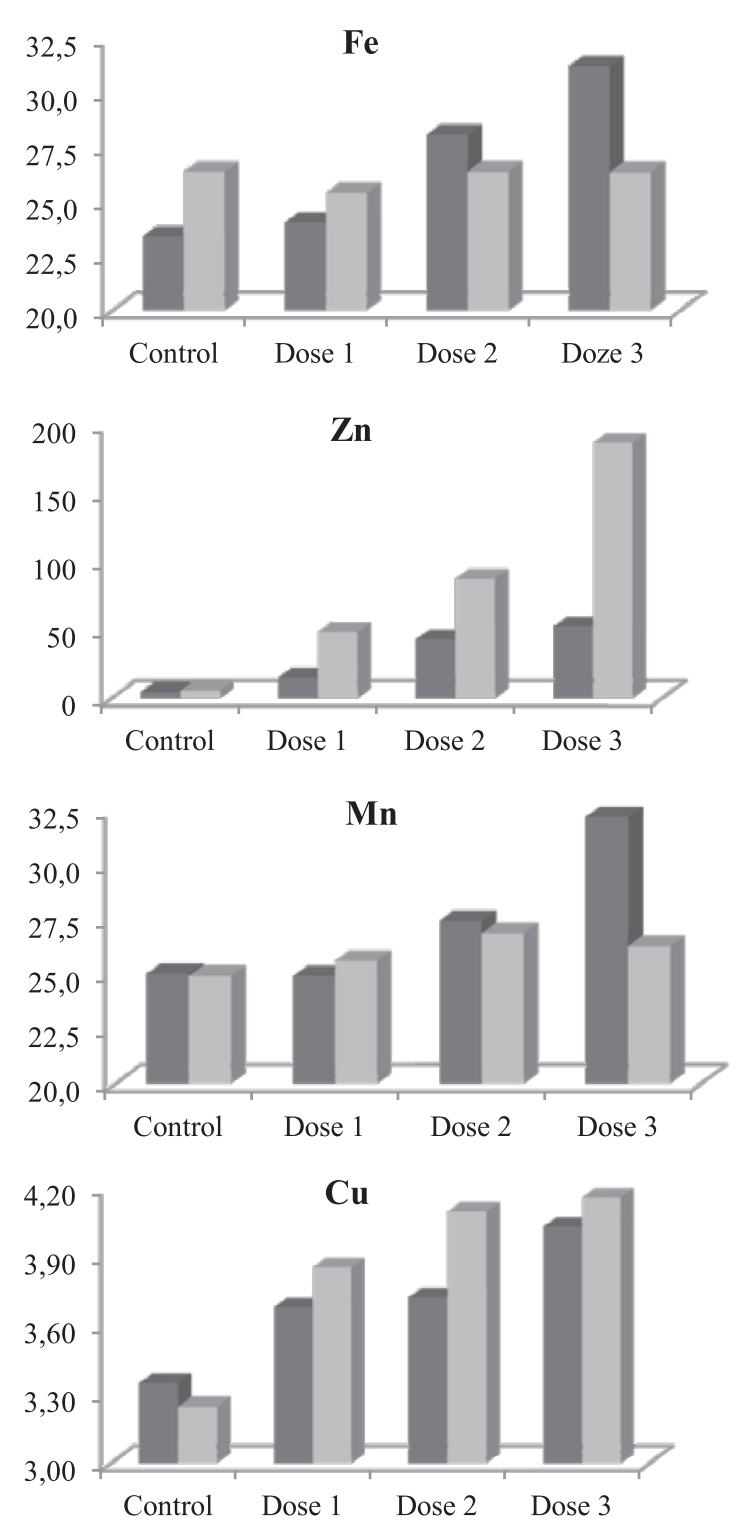

Fig. 4. Effect of increasing amounts of limed sludge on the Fe, $\mathrm{Zn}, \mathrm{Mn}$ and $\mathrm{Cu}$ contents of pre-planting and post-harvest soil.
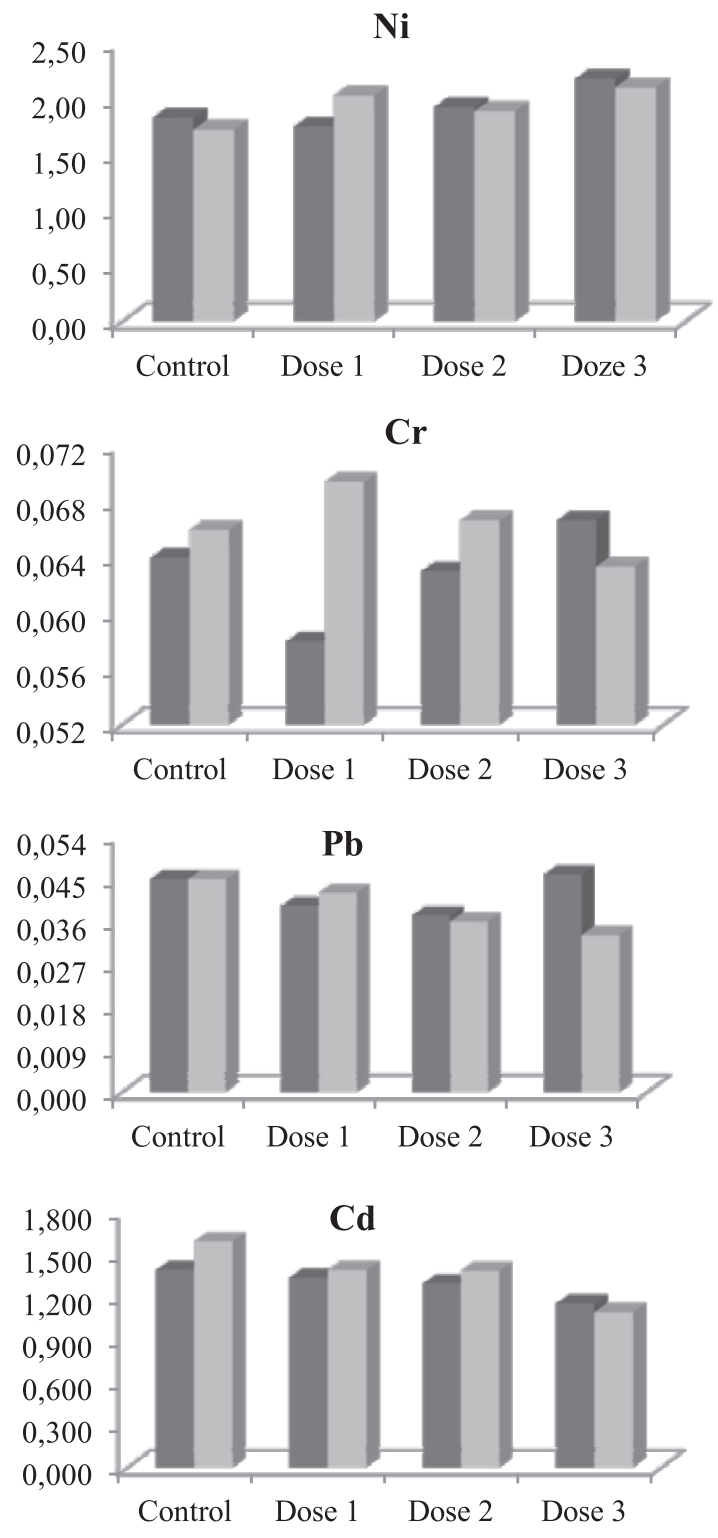

Fig. 5. Effect of increasing amounts of limed sludge on the Ni, $\mathrm{Cr}, \mathrm{Pb}$ and $\mathrm{Cd}$ contents of pre-planting and post-harvest soil. 
Table 6. Effect of increasing amounts of limed sludge on the $\mathrm{Ni}, \mathrm{Cr}, \mathrm{Pb}$ and $\mathrm{Cd}$ contents of pre-planting and post-harvest soil.

\begin{tabular}{|c|c|c|c|c|c|c|c|c|c|c|c|c|}
\hline \multirow{2}{*}{$\begin{array}{l}\text { Treatments tons } \\
\qquad \mathrm{ha}^{-1}\end{array}$} & \multicolumn{3}{|c|}{$\mathrm{Ni}, \mathrm{mg} \mathrm{kg}^{-1}$} & \multicolumn{3}{|c|}{$\mathrm{Cr}, \mathrm{mg} \mathrm{kg}^{-1}$} & \multicolumn{3}{|c|}{$\mathrm{Pb}, \mathrm{mg} \mathrm{kg}^{-1}$} & \multicolumn{3}{|c|}{$\mathrm{Cd}, \mathrm{mg} \mathrm{kg}^{-1}$} \\
\hline & BS & $\mathrm{AH}$ & Means & BS & $\mathrm{AH}$ & Means & BS & $\mathrm{AH}$ & Means & BS & $\mathrm{AH}$ & Means \\
\hline Control & 1,83 & 1,72 & 1,78 & 0,064 & 0,066 & 0,065 & 1,392 & 1,595 & 1,494 & 0,045 & 0,045 & 0,045 \\
\hline 30 & 1,75 & 2,03 & 1,89 & 0,058 & 0,069 & 0,064 & 1,338 & 1,393 & 1,366 & 0,039 & 0,042 & 0,041 \\
\hline 60 & 1,93 & 1,89 & 1,91 & 0,063 & 0,067 & 0,065 & 1,295 & 1,388 & 1,342 & 0,037 & 0,036 & 0,037 \\
\hline 90 & 2,18 & 2,10 & 2,14 & 0,067 & 0,063 & 0,065 & 1,155 & 1,089 & 1,122 & 0,046 & 0,033 & 0,040 \\
\hline Means. & 1,92 & 1,94 & & 0,063 & 0,066 & & 1,295 & 1,366 & & 0,042 & 0,039 & \\
\hline \multicolumn{13}{|c|}{ BS: before sowing, AH: After harvest } \\
\hline Dose & & & nd & & & nd & & & nd & & & nd \\
\hline Period & & & nd & & & nd & & & nd & & & nd \\
\hline $\mathrm{D} * \mathrm{P}$ & & & nd & & & nd & & & nd & & & nd \\
\hline
\end{tabular}

$* . \mathrm{p}<0,05, * * . \mathrm{p}<0,01$

and thus metals were strongly fixed in the inorganic fractions of the sludge, becoming more insoluble due to adsorption/precipitation processes. Strong retention of metals is often attributed to the inorganic fraction of sludge, while the strength and capacity of metal sorption by sludge can be increased through the addition of lime, as reported in previous studies [43].

The release, movement and uptake of heavy metals concomitant with wastewater sludge are influenced by a number of factors such as soil type on which wastewater sludge is applied, $\mathrm{pH}$, soil organic matter, redox potential, and metal bindings [44]. In particular, the amount of extractable heavy metals has significantly decreased in the lime-stabilized sludge. No increase was observed in heavy metal content of soil due to immobilization at increasing levels of sludge applications.

\section{Effects of Lime-Stabilized Sludge on Plant Growth}

The results related to changes caused by lime treatment sludge on plant growth, grain and root nutrients and heavy metal content were given and grouped according to LSD test in Tables 7 and 8 . When Table 7 is examined, it is determined that the plant $\mathrm{P}$, $\mathrm{K}, \mathrm{Mg}$ and $\mathrm{Ca}$ contents have increased depending on increasing application levels, but decreased depending on time except $\mathrm{Ca}$. Root nitrogen content also increased due to the increased application level. Increases depending on the application levels are related to the chemical properties of the sludge.

The changes in the nitrogen content of the plant due to increasing levels are insignificant, which may be caused by the applied lime to the sludge, which decreased the availability of nitrogen. Depending on the sampling periods, the decrease in the plant nutrient elements is considered to be due to the fact that the plant nutrient intake is fast at the beginning of development and decreases depending on time and dilution effect.

They reported a rapid decrease in the period of development and fluctuations in $\mathrm{N}$ and $\mathrm{P}$ in later periods. This change seen in the leaves is consistent with the reports of the study $[45,46] . \mathrm{K}$ reached peak value $(2.360 \%)$ at the time when photosynthesis and water uptake were highest, then decreased and remained almost stable in other periods. $\mathrm{K}$ is not located in the structure of organic matter and is involved in the transport of water, especially of the plant and the transportation of photosynthesis products [47].

It is thought that $\mathrm{Ca}$ increases continuously depending on time related to the application of lime to the sludge and increase of $\mathrm{Ca}$ content. Calcium is transported to the leaves with transpiration. Although $\mathrm{N}, \mathrm{P}, \mathrm{Mg}$ and $\mathrm{K}$ ions can be easily carried in the phloem, some researchers have indicated that the $\mathrm{Ca}$ ion is transported very slightly and slowly and it reaches the newly developing meristematic tissues by transpiration, in xylem, As a result of very little or no phloem transport of calcium and the fruits did not transpirate, $\mathrm{Ca}$ cannot be moved to newly developing tissues such as fruits, and a continuous increase was observed in the leaves [48].

When Table 8 was examined, the content of plant grain and root $\mathrm{Fe}$ increased with increasing application levels. The $\mathrm{Cu}$ content of the plant increased depending on time, but an increase also was observed in the $\mathrm{Cu}$ content of the root. The most pronounced effect in the study was in the plant $\mathrm{Zn}$ content. The $\mathrm{Zn}$ content of the plant has increased significantly depending on the application levels and sampling periods. Similarly, it increased with time. it is important to note that the $\mathrm{Zn}$ availability in soil shows a good correlation with the amount of this nutrient in the plant shoots [49]. However, $\mathrm{Zn}$ content in plants in soil amended with alkaline sewage sludge contrasted with a decrease of $\mathrm{Zn}$ with the isolated application of lime was expressed [50]. 
Table 7. Effect of lime treatment sludge on macro elements in corn plants.

\begin{tabular}{|c|c|c|c|c|c|c|}
\hline \multicolumn{7}{|c|}{ Sampling Periods } \\
\hline \multicolumn{7}{|c|}{ Nitrogen $(\mathrm{N}), \%$} \\
\hline Tons ha ${ }^{-1}$ & V3 & $\mathrm{R} 1$ & $\mathrm{R} 5$ & Means & Grain & Root \\
\hline Control & 2,598 & 2,845 & 2,053 & 2,499 & 1,453 & $1,064 C^{*}$ \\
\hline 30 & 2,786 & 2,714 & 1,966 & 2,489 & 1,516 & $1,167 \mathrm{BC} *$ \\
\hline 60 & 2,95 & 2,784 & 1,995 & 2,576 & 1,546 & $1,382 \mathrm{AB}^{*}$ \\
\hline 90 & 2,694 & 2,789 & 2,062 & 2,515 & 1,596 & $1,611 A^{*}$ \\
\hline Means & $2,757 A^{* *}$ & $2,783 \mathrm{~A}^{* *}$ & $2,019 \mathrm{~B} * *$ & & & \\
\hline LSD Dose & & & & nd & nd & 0,238 \\
\hline Period & & & & 0,197 & & \\
\hline \multicolumn{7}{|c|}{ Phosphorus (P), \% } \\
\hline Control & 0,196 & 0,180 & 0,159 & 0,178 & 0,187 & 0,176 \\
\hline 30 & 0,203 & 0,183 & 0,159 & 0,182 & 0,193 & 0,203 \\
\hline 60 & 0,253 & 0,183 & 0,160 & 0,199 & 0,187 & 0,199 \\
\hline 90 & 0,258 & 0,236 & 0,181 & 0,225 & 0,164 & 0,185 \\
\hline Means & 0,228 & 0,196 & 0,165 & & & \\
\hline LSD Dose & & & & nd & nd & nd \\
\hline Period & & & & nd & & \\
\hline \multicolumn{7}{|c|}{ Potassium (K), \% } \\
\hline Control & 2,197 & 1,084 & 1,000 & $1,427 \mathrm{~B}^{*}$ & 0,151 & 1,913 \\
\hline 30 & 2,481 & 1,125 & 1,076 & $1,561 \mathrm{AB}^{*}$ & 0,164 & 1,977 \\
\hline 60 & 2,378 & 1,213 & 1,127 & $1,573 A^{*}$ & 0,163 & 1,993 \\
\hline 90 & 2,383 & 1,223 & 1,277 & $1,628 A^{*}$ & 0,132 & 2,294 \\
\hline Means & $2,360 A^{* *}$ & $1,161 \mathrm{~B} * *$ & $1,120 \mathrm{~B}^{* *}$ & & & \\
\hline LSD Dose & & & & 0,134 & nd & nd \\
\hline Period & & & & 0,116 & & \\
\hline \multicolumn{7}{|c|}{ Calcium (Ca), \% } \\
\hline Control & 0,282 & 0,485 & 0,601 & $0,456 B^{*}$ & 0,012 & $0,056 C^{*}$ \\
\hline 30 & 0,366 & 0,534 & 0,589 & $0,496 \mathrm{AB}^{*}$ & 0,012 & $0,183 \mathrm{~B}^{*}$ \\
\hline 60 & 0,399 & 0,545 & 0,624 & $0,523 A^{*}$ & 0,011 & $0,265 \mathrm{~B}^{*}$ \\
\hline 90 & 0,466 & 0,590 & 0,626 & $0,561 A^{*}$ & 0,020 & $0,529 A^{*}$ \\
\hline Means & $0,378 C * *$ & $0,539 B * *$ & $0,610 A^{* *}$ & & & \\
\hline LSD Dose & & & & 0,065 & nd & 0,121 \\
\hline Period & & & & 0,056 & & \\
\hline \multicolumn{7}{|c|}{ Magnesium (Mg), \% } \\
\hline Control & 0,112 & 0,074 & 0,065 & 0,084 & 0,087 & $0,175 C^{* *}$ \\
\hline 30 & 0,125 & 0,078 & 0,060 & 0,088 & 0,084 & $0,268 \mathrm{~B} * *$ \\
\hline 60 & 0,128 & 0,075 & 0,070 & 0,091 & 0,079 & $0,328 A^{* *}$ \\
\hline 90 & 0,141 & 0,055 & 0,068 & 0,088 & 0,066 & $0,247 \mathrm{~B} * *$ \\
\hline Means & $0,127 A^{* *}$ & $0,071 B * *$ & $0,066 \mathrm{~B} * *$ & & & \\
\hline LSD & & & & nd & nd & 0,025 \\
\hline \multicolumn{2}{|l|}{ Period } & & & 0,021 & & \\
\hline
\end{tabular}


Table 8. Effect of lime treatment sludge on some micronutrients and heavy metals content in corn plants.

\begin{tabular}{|c|c|c|c|c|c|c|}
\hline \multicolumn{7}{|c|}{ Sampling Periods } \\
\hline & V3 & $\mathrm{R} 1$ & $\mathrm{R} 5$ & Means & Grain & Root \\
\hline \multicolumn{7}{|c|}{ Iron $(\mathrm{Fe}), \mathrm{mg} \mathrm{kg}^{-1}$} \\
\hline Control & 102,41 & 103,69 & 106,90 & $104,33 B^{*}$ & $14,023 \mathrm{~B}^{*}$ & $6277 B^{*}$ \\
\hline 30 & 108,70 & 107,93 & 107,97 & $108,20 B^{*}$ & $14,547 \mathrm{~B}^{*}$ & $7262 B^{*}$ \\
\hline 60 & 107,14 & 121,50 & 110,08 & $112,91 \mathrm{~B}^{*}$ & $15,253 \mathrm{~B}^{*}$ & 7292B* \\
\hline 90 & 119,40 & 128,93 & 112,90 & $120,41 A^{*}$ & $19,483 A^{*}$ & $10358 A^{*}$ \\
\hline Means & 109,41 & 115,51 & 109,46 & & & \\
\hline LSD Dose & & & & 10,576 & 9,570 & 2325,3765 \\
\hline Period & & & & nd & & \\
\hline \multicolumn{7}{|c|}{ Copper $(\mathrm{Cu}), \mathrm{mg} \mathrm{kg}^{-1}$} \\
\hline Control & 9,135 & 9,358 & 10,434 & 9,642 & 0,917 & 13,597 \\
\hline 30 & 9,850 & 10,870 & 10,151 & 10,290 & 1,269 & 14,793 \\
\hline 60 & 8,651 & 10,316 & 11,023 & 9,997 & 1,139 & 15,280 \\
\hline 90 & 8,407 & 10,363 & 11,238 & 10,003 & 1,389 & 16,457 \\
\hline Means & $9,012 B *$ & $10,227 A^{*}$ & $10,712 A^{*}$ & & & \\
\hline LSD Dose & & & & nd & nd & nd \\
\hline Period & & & & 1,104 & & \\
\hline \multicolumn{7}{|c|}{ Zinc (Zn), $\mathrm{mg} \mathrm{kg}^{-1}$} \\
\hline Control & 35,420 & 47,680 & 56,830 & $46,643 \mathrm{~B} * *$ & 18,937 & $43,08 C^{* *}$ \\
\hline 30 & 34,257 & 48,843 & 59,703 & $47,601 \mathrm{~B} * *$ & 21,243 & $128,65 \mathrm{~B} * *$ \\
\hline 60 & 40,713 & 62,923 & 80,660 & $61,432 A^{* *}$ & 21,277 & $205,20 \mathrm{~B} * *$ \\
\hline 90 & 51,737 & 68,667 & 61,217 & $60,540 \mathrm{~A}^{* *}$ & 20,677 & $494,33 A^{* *}$ \\
\hline Means & $40,531 \mathrm{C}^{* *}$ & $57,028 \mathrm{~B} * *$ & $64,603 \mathrm{~A}^{* *}$ & & & \\
\hline LSD Dose & & & & 8,463 & nd & 80,068 \\
\hline Period & & & & 7,329 & & \\
\hline \multicolumn{7}{|c|}{ Manganese (Mn), $\mathrm{mg} \mathrm{kg}^{-1}$} \\
\hline Control & 41,017 & 68,277 & 86,843 & 65,379 & 7,810 & $165,97 \mathrm{~B} * *$ \\
\hline 30 & 40,560 & 80,623 & 97,200 & 72,794 & 7,968 & $187,27 \mathrm{~A}^{* *}$ \\
\hline 60 & 41,533 & 85,780 & 99,673 & 75,662 & 6,725 & $177,70 \mathrm{AB}^{* *}$ \\
\hline 90 & 45,133 & 80,063 & 81,857 & 69,018 & 6,213 & $162,77 \mathrm{~B} * *$ \\
\hline Means & $42,061 C^{* *}$ & $78,686 \mathrm{~B} * *$ & $91,393 A^{* *}$ & & & \\
\hline LSD Dose & & & & nd & nd & 17,219 \\
\hline Period & & & & 8,552 & & \\
\hline \multicolumn{7}{|c|}{ Cadmium (Cd), $\mathrm{mg} \mathrm{kg}^{-1}$} \\
\hline Control & 0,052 & 0,027 & 0,030 & 0,036 & 0,053 & 0,138 \\
\hline 30 & 0,052 & 0,034 & 0,049 & 0,045 & 0,061 & 0,102 \\
\hline 60 & 0,051 & 0,051 & 0,054 & 0,052 & 0,076 & 0,139 \\
\hline 90 & 0,064 & 0,052 & 0,063 & 0,060 & 0,104 & 0,138 \\
\hline Means & 0,055 & 0,041 & 0,049 & & & \\
\hline
\end{tabular}


Table 8. Continued.

\begin{tabular}{|c|c|c|c|c|c|c|}
\hline LSD Dose & & & & nd & nd & nd \\
\hline Period & & & & nd & & \\
\hline \multicolumn{7}{|c|}{ Chromium (Cr), mg kg-1 } \\
\hline Control & 2,340 & 4,591 & 3,620 & $3,517 C^{*}$ & 0,427 & 56,053 \\
\hline 30 & 2,676 & 3,314 & 3,639 & $3,210 \mathrm{BC} *$ & 0,436 & 40,193 \\
\hline 60 & 2,795 & 3,976 & 3,343 & $3,37 \mathrm{AB} *$ & 0,445 & 43,627 \\
\hline 90 & 3,662 & 3,893 & 3,629 & $3,728 A^{*}$ & 0,577 & 52,563 \\
\hline Means & 2,868 & 3,944 & 3,558 & & & \\
\hline LSD Dose & & & & nd & nd & nd \\
\hline Period & & & & 0,451 & & \\
\hline \multicolumn{7}{|c|}{ Nickel (Ni), mg kg-1 } \\
\hline Control & 1,229 & 1,353 & 1,247 & 1,276 & $0,675 \mathrm{~B} *$ & 35,833 \\
\hline 30 & 1,263 & 1,065 & 1,095 & 1,141 & $1,573 \mathrm{~A}^{*}$ & 43,337 \\
\hline 60 & 1,288 & 1,323 & 1,153 & 1,255 & $1,851 \mathrm{~A}^{*}$ & 33,940 \\
\hline 90 & 1,458 & 1,348 & 0,958 & 1,255 & $1,947 A^{*}$ & 39,917 \\
\hline Means & $1,310 A^{*}$ & $1,272 A^{*}$ & $1,113 B *$ & & & \\
\hline LSD Dose & & & & nd & 0,640 & nd \\
\hline Period & & & & 0,149 & & \\
\hline \multicolumn{7}{|c|}{ Lead $(\mathrm{Pb}), \mathrm{mg} \mathrm{kg}^{-1}$} \\
\hline Control & 0,609 & 0,580 & 0,649 & $0,613 A^{*}$ & 0,690 & $4,578 C^{*}$ \\
\hline 30 & 0,383 & 0,521 & 0,623 & $0,509 \mathrm{AB}^{*}$ & 0,844 & $5,657 \mathrm{~B}^{*}$ \\
\hline 60 & 0,580 & 0,56 & 0,137 & $0,426 \mathrm{BC} *$ & 0,887 & $4,647 \mathrm{C}^{*}$ \\
\hline 90 & 0,471 & 0,576 & 0,034 & $0,360 C^{*}$ & 0,880 & $6,652 A^{*}$ \\
\hline Means & 0,511 & 0,559 & 0,361 & & & \\
\hline LSD Dose & & & & 0,111 & nd & 0,845 \\
\hline Period & & & & nd & & \\
\hline
\end{tabular}

*. $\mathrm{p}<0,05, \quad * * . \mathrm{p}<0,01$

The changes that occurred in the $\mathrm{Cd}$ content of the plant depending on the applications and sampling periods were not significant. The $\mathrm{Cr}$ content of the plant increased with both the application levels and the sampling periods. $\mathrm{Ni}$ and $\mathrm{Pb}$ content decreased with sampling periods and increasing levels of application. However, the amount of $\mathrm{Ni}$ in grain increased with increasing application levels. Increases in the amount of plant root heavy metal were observed in the study, depending on the increasing levels.

It is well documented that wastewater sludge application to soils substantially increases nutrient content and crop growth [51] as well as improves soil properties. [52] noticed that the accumulation of heavy metals in the treated crops were under allowable limits. On the contrary, [53] noticed that heavy metals were increased above allowable limits in soil and plants by increasing sludge applications. Certain plant mechanisms render the decrease in uptake at high metal loadings [54]. These mechanisms include exclusion of metals, limited translocation from root to shoot and saturation of the metal transport channels at high metal concentrations [55]. Negative effects of sludge application such as elevated heavy metal content in parts of plants resulting from the use of lime-stabilized sludge must also be taken into consideration.

\section{Conclusions}

It was known that when wastewater treatment sludges were applied to the soil for agricultural purposes, the soil salinity and heavy metal content 
increases in particular. This may lead to increases in heavy metal content due to increased application levels. According to the results obtained within the scope of the study; applied food-based and lime-applied sludge, increased soil organic matter, $\mathrm{N}$ and $\mathrm{P}$ contents at the point of improvement of soil properties. The most notable change has come to the zinc content of the soil and the plant. It was known that this is an important problem in agricultural productivity in which zinc was a plant nutrient and the zinc content of agricultural soils was generally low and fertilizing was needed. It can be concluded that the so-called treatment sludge, which was thought to have no adverse properties, can be applied in soil with calcareous and low zinc content.

In general, lime stabilization decreased the total extractability of heavy metals, indicating a reduced bioavailability of these elements. This is particularly important for safe utilization in agricultural soils in order to reduce the transfer of heavy metals to the food chain. However, at the point of these applications it was necessary to determine the optimum application level for different soil characteristics and plants.

\section{Acknowledgements}

The authors would like to thank the Research and Development Department employees of the Natura Food Industry and Trade Inc. in Bursa, Turkey.

\section{Conflict of Interest}

The authors declare no conflict of interest.

\section{References}

1. FARZADKİA M., BAZRAFSHAN E. Lime stabilization of waste activated sludge; Health Scope, 3 (1), e16035, 2014.

2. TSADILAS C.D. Heavy metals forms in biosolids, soils and biosolid-amended soils. In: Selim H.M. (ed.) Dynamics and bioavailability of heavy metals in the rootzone; CRC Press, Taylor and Francis Group, Boca Raton, 2011.

3. LARNEY F.J., ANGERS D.A. The role of organic amendments in soil reclamation: a review; Can Journal Soil Sci. 92,19, 2012.

4. LU Q., HE Z.L., STOFFELLA P.J. Land application of biosolids in the USA: a review; Appl Environ Soil Sci. 1, $1,2012$.

5. HANNAH R., BRADLEY O.C., DEBORAH L.P., BARRY M., FIREW B., STEPHEN R.S., NICHOLA A.P. A critical review of nitrogen mineralization in biosolids-amended soil, the associated fertilizer value for crop production and potential for emissions to the environment. Science of the Total Environment, 541, 1310, 2016.

6. USMAN K., KHAN S., GHULAM S., KHAN M.U., KHAN N., KHAN M.A., KHALIL S.K. Sewage sludge: an important biological resource for sustainable agriculture and its environmental implications; Am. J. Plant Sci. 3, 1708, 2012.

7. DALPISOL, M., SERRAT, B.M., MOTTA, A.C.V., POGGERE, G.C., BITTENCOURT, S., BARBOSA, J.Z. Zinc, copper and manganese availability in soils treated with alkaline sewage sludge from Paraná state (Brazil); Ciência e Agrotecnologia, 41 (1), 85, 2017.

8. JAMAL A., NORIEH N., FARZADKIA M. Comparison of aerobic and lime stabilization methods for evaluation of sewage sludge reuse; Journal of Environmental Science and Technology, 4 (2), 182, 2011.

9. VIEIRA R.F., MORICONI W., PAZIANOTTO R.A.A. Residual and cumulative effects of soil application of sewage sludge on corn productivity; Environ. Sci. Pollut. Res. 21 (10), 6472, 2014.

10. MAHAPATRA K., RAMTEKE D.S., PALIWAL L.J., NAIK N.K. Agronomic application of food processing industrial sludge to improve soil quality and crop productivity; Geoderma. 207-208, 205, 2013.

11. KULIKOWSKA D., KLIK B.K., GUSIATIN Z.M. HAJDUKIEWICZ K. Characteristics of humic substances from municipal sewage sludge: a case study, Desalination and Water Treatment, 144, 57, 2019.

12. TEODOR K., ANNA K.K., HENRYK C.. Yielding and Heavy Metals accumulation in the biomass of grass cultivated in substrata with the participation of municipal sewage sludge and green waste compost. Pol. J. Environ. Stud. 25 (5), 2009, 2016.

13. TZIACHRIS P., LEKAKIS E., ZAMBETOGLOU K., METAXA I., PAPADOPOULOS F. A case study of the effects of sewage sludge application on soil properties and heavy metal availability in the Thessaloniki plain (Greece); Waste Biomass Valorization. 8, 1803, 2017.

14. MANEA E., MANEA D., ROBESCU D.N. Environmental risks of wastewater sludge disposal. Environmental Engineering and Management Journal, 12 (1), 79, 2013.

15. COCARTA M., SUBTIRELU V.R., BADEA A. Effect of sewage sludge application on wheat crop productivity and heavy metal accumulation in soil and wheat grain. Environmental Engineering and Management Journal, 16 (5), 1093, 2017.

16. WANG S., LIU X., ZHENG Q., YANG Z., ZHANG R., YIN B. Characteristics and feasibility study of sewage sludge for landscaping application in Xi'an, China. Environmental Engineering and Management Journal, 12 (7), 1515, 2013.

17. NİLSSON S.I., JHONSON L., JENNISCHE P. Sludge, Treated Biowaste and Soil-Determination of $\mathrm{pH}$, A horizontal Standard for $\mathrm{pH}$ measurement-The influence on $\mathrm{pH}$ measurements of sample pretreatment, ionic composition/ionic strength of the extractant and centrifugation/filtration. Swedish University of Agricultural Sciences, Uppsala, 2005a.

18. NİLSSON S.I., JHONSON L., JENNISCHE P. Sludge, Treated Biowaste and Soil-Determination of Specific Electrical Conductivity, Desk study to assess the feasibility of a draft horizontal standard for electrical conductivity. Swedish University of Agricultural Sciences, Uppsala, 2005b.

19. ANONYMOUS, (EN 12880), ChemicalAnalysesDetermination of dry matter and water content on a mass basis in sediment, sludge, soil and waste- Gravimetric method, 2003.

20. MAYNARD D.G., KALRA Y.P., CRUMBAUGH J.A. Nitrate and exchangeable ammonium nitrogen, Eds: M.R. Carter and E.G. Gregorich, Soil sampling and methods 
of analysis $\left(2^{\text {nd }}\right.$ edition). CRC Press, Taylor and Francis Group, Boca Raton, 1264, 2007.

21. TUREK, A., WİECZOREK, K., WOLF, W.M. Digestion procedure and determination of heavy metals in sewage sludge - an analytical problem; Sustainability, 11, 1753, 2019.

22. KACAR B. Soil Analysis. Nobel Publishers, Ankara, 466, 2012.

23. KACAR B. Plant, Soil and Fertilizer Analysis 2: Nobel Publishers, Ankara, 423, 2014.

24. LU X., BOTTOMLY P.J. Contribution of Ammonia oxidizing orchaea and bacteria to nitrification in Oregon forest soils. Soil Biology and Biochemistry. 85, 54, 2015.

25. AHMED H.K., FAWY H.A., ABDEL-HADY E.S. Study of sewage sludge use in agriculture and its effect on plant and soil. Agric Biol J N Am 1, 1044, 2010.

26. ZUO W., GU C., ZHANG W., XU K., WANG Y., BAİ Y., SHAN Y., DAİ Q. Sewage sludge amendment improved soil properties and sweet sorghum yield and quality in a newly reclaimed mudflat land; Science of the Total Environment, 654, 541, 2019.

27. AŞIK B.B., AYDINALP C., SAGBAN F.O.T., KATKAT A.V. Effects of application of different sewage sludge on loamy texture soil and plant growth. Fresenius Environmental Bulletin, 22 (9), 1182, 2013.

28. AŞIK B.B., AYDINALP C., KATKAT A.V., SAGBAN F.O.T. Effect of the application of various wastewater sludges on the properties of sandy soil. Environmental Monitoring and Assessment, 187, 30, 2015.

29. SHARMA B., VAISH B., MONIKA SINGH U.K., SINGH P., SINGH R.P. Recycling of organic wastes in agriculture: An environmental perspective; International Journal of Environmental Research, 13, 409, 2019.

30. ISABELA D., ANTONIO M., MATEUS M., ALISSON B., ADRİANA W. Degradation rate of limed sewage sludge in an agricultural soil; Environmental Engineering \& Management Journal, 18 (5), 1049, 2019.

31. ALVARENGA P., MOURINHA C., FARTO M., SANTOS T., PALMA P., SENGO J., MORAIS M.C., QUEDA C.C. Sewage sludge, compost and other representative organic wastes as agricultural soil amendments: Benefits versus limiting factors; Waste Management, 40, 44, 2015.

32. LIU H. Achilles heel of environmental risk from recycling of sludge to soil as amendment: A summary in recent ten years (20072016); Waste Management, 56, 575, 2016.

33. SHARMA B., SARKAR A., SINGH P., SINGH R.P. Agricultural utilization of biosolids: A review on potential effects on soil and plant grown; Waste Management, 64, 117, 2017.

34. ZARE L., RONAGHI A. Comparison of $\mathrm{N}$ mineralization rate and pattern in different manure- and sewage sludgeamended calcareous soil; Communications in Soil Science and Plant Analysis, 50 (5), 559, 2019.

35. EPA. Environmental Guidelines: Use and Disposal of Biosolid Products. NSW Environment Protection Agency, Sydney, 1997.

36. DEC. Western Australian Guidelines for Biosolids Management. Department of Environment and Conservation, Perth. 2012.

37. WHITE J.W., COALE F.J., SIMS J.T., SHOBER A.L. Phosphorus runoff from wastewater treatment biosolids and poultry litter applied to agricultural soils; J Environ Qual. 39, 314, 2010.

38. ISLAS-ESPINOZA M., SOLIS-MEJIA L., ESTELLER M.V. Phosphorus release kinetics in a soil amended with biosolids and vermicompost; Environ Earth Sci. 71, 1441, 2014.

39. QIN C., LIU H., LIU L., SMITH S., SEDLAK D.L., GU A.Z. Bioavailability and characterization of dissolved organic nitrogen and dissolved organic phosphorus in wastewater effluents; Sci Total Environ. 511, 47, 2015.

40. LI Q., LI J.M., CUI X.L., WEI D.P., MA Y.B. On-farm assessment of biosolids effects on nitrogen and phosphorus accumulation in soils; J. Integr. Agr. 11 (9), 1545, 2012.

41. ITICESCUA C., GEORGESCU L.P., MURARIU G., CIRCIUMARU A., TIMOFTI $M$. The characteristics of sewage sludge used on agricultural lands; Recent Advances on Environment, Chemical Engineering and Materials, AIP Conference Proceedings. 2022, 020001, 2018.

42. AŞIK B.B., AYDINALP C., SAGBAN F.O.T., KATKAT A.V. Agricultural use of wastewater sludge from various sources with special emphasis on total and DTPAextractable heavy metal content, Environment Protection Engineering, 42 (1), 45, 2016.

43. ANGIN İ., YAĞANOĞLU A.V. Effects of sewage sludge application on some physical and chemical properties of a soil affected by wind erosion, Journal of Agricultural Science and Technology, 13 (5), 757, 2011.

44. MALARA A., OLESZCZUK P. Application of a battery of biotests for the determination of leachate toxicity to bacteria and invertebrates from sewage sludge-amended soil; Environ. Pollution Res. 20 (5), 3435, 2013.

45. YONEYAMA T., TANNO F., TATSUMI J., MAE T. Whole-plant dynamic system of nitrogen use for vegetative growth and grain filling in rice plants (Oryza sativa L.) as revealed through the production of 350 grains from a germinated seed over 150 days: A Review and Synthesis Front. Plant Sci. 7, 1151, 2016.

46. MALHOTRA H., VANDANA SHARMA S., PANDEY R. Phosphorus nutrition: Plant growth in response to deficiency and excess. In book: Plant Nutrients and Abiotic Stress Tolerance, Springer, 171, 2018.

47. HASANUZZAMAN M., BORHANNUDDİN BHUYAN M.H.M., NAHAR K., HOSSAIN S., AL MAHMUD J., HOSSEN S., MASUD A.A.C., FUJITA M., Potassium: A vital regulator of plant responses and tolerance to abiotic stresses; Agronomy, 8, 31, 2018.

48. HOCKING B., TYERMAN S.D., BURTON R.A., GILLIHAM M. Fruit Calcium: Transport and Physiology; Front. Plant Sci. 7, 569, 2016.

49. SOBRAL L.F., SMYTH J.T., FAGERIA N.K., STONE L.F. Comparison of copper, manganese, and zinc extraction with Mehlich 1, Mehlich 3, and DTPA solutions for soils of the Brazilian coastal tablelands; Communications in Soil Science and Plant Analysis. 44 (17), 2507, 2013.

50. PONTONI, D. R. Nutrição e crescimento do feijoeiro (Phaseolus vulgaris L.) em função de lodo de esgoto e calcário para solos subtropicais. Available in: http:// acervodigital.ufpr.br/handle/1884/26258 (November, 08, 2019)

51. SINGH R.P., AGRAWAL M. Effect of different sewage sludge applications on growth and yield of Vigna radiata L. field crop: Metal uptake by plant; Ecological Engineering. 36, 969, 2010.

52. LIU T., LIU B., ZHANG W. Nutrients and heavy metals in biochar produced by sewage sludge pyrolysis: its application in soil amendment; Pol. J. Environ. Stud. 23 (1), 271, 2014.

53. SOLANKI P., AKULA B., SHARMA S.H.K., REDDY D.J. Physico-chemical properties of sewage sludge 
and its impact on soil fertility; International Journal of Advanced Technolgy in Engineering and Science, 4 (10), $1,2016$.

54. CHU S., WU D., LIANG L.L., ZHONG F., HU Y., HU, X., LAI, C., ZENG, S. Municipal sewage sludge compost promotes Mangifera persiciforma tree growth with no risk of heavy metal contamination of soil; Scientific Reports, 7, 13408, 2017.

55. SINGH M., KUMAR J., SINGH S., SINGH V.P., PRASAD S.M., SINGH M.P.V.V.B. Adaptation Strategies of Plants against Heavy Metal Toxicity: A Short Review; Biochem Pharmacol (Los Angel), 42 (2), 1000161, 2015. 